Fish parasitology

\title{
DEVELOPMENT OF HAEMOGREGARINES (APICOMPLEXA), BLOOD \\ PARASITES OF EEL, ANGUILLA ANGUILLA (L.)
}
ROZWÓJ HAEMOGREGARIN (APICOMPEXA), PASOZZYTÓW KRWI WĘGORZA, ANGUILLA ANGUILLA (L.)

\author{
${ }^{1}$ Department of Animal Ecology, Szczecin University, Poland \\ ${ }^{2}$ Department of Fish Diseases, Agricultural University of Szczecin, Poland
}

\begin{abstract}
Haemogregarines were found in 23 (2.8\%) out of 820 eel, Anguilla anguilla (L.) individuals caught in the Szczecin Lagoon and lakes Dąbie, Siecino, Drawsko, and Lipiany (northwestern Poland). Different developmental stages were present predominantly in the leukocytes and extracellularly; more seldom, they occurred also in the peripheral blood erythrocytes, in the liver, spleen, and kidney. Merogony involving different stages with nuclear chromatin aggregated into $2,4,8,16,32$ and more groups within a cell was followed. During the subsequent differentiation, chromatin shifted to the cell periphery and merozoites (up to 32 and more), attached to the residual body, were formed by separation. The released merozoites were scattered between cells. During gamogony, gamont-resembling forms were formed as a stage terminating development in the fish host.
\end{abstract}

\section{INTRODUCTION}

Haemogregarines have been most often recorded in fish erythrocytes (Laird and Bullock 1969; Khan 1972, 1978; Eiras and Davies 1991; Khan et al. 1992; Eiras et al. 1995; and other authors). Franca (1908) described an intra-erythrocytal form found in the blood of eel, Anguilla anguilla (L.) in Portugal, as a new species, Haemogregarina bettencourti. As reported by Franca (1908), H. lignieres Laveran, 1906 was somewhat earlier described in the erythrocytes of Anguilla sp. in Argentine.

A complete haemogregarine life cycle was described by Khan (1978) who followed the development of Cyrilia uncinata (Khan, 1978) in erythrocytes of the peripheral blood, heart, and kidney of the marine fish Lycodes lavalei and $L$. vahli as well as in the intestine 
of the leech Johanssonia sp. Subsequently, Lainson (1981) (as referred to by Lom and Dyková 1992) described the life cycle of $C$. gomesi (Neiva et Pinto, 1926), involving two hosts: the freshwater fish Synbranchus marmoratus from Brazil and the leech Haementeria lutzi. The life cycle of Haemogregarina bigemina Laveran et Mesnil, 1901 was studied by Davies (1982) in the marine fish Blennius pholis, the subsequent stages living in the intestine of Gnathia maxillaris (Isopoda). These studies were continued by Davies et al. (1994). Some papers deal only with developmental stages occurring in naturally infected fish erythrocytes. Those papers concem, i.a., H. delagei Laveran et Mesnil, 1901 studied by Khan (1972) and H. bigemina, studied by Eiras and Davies (1991). Kirmse (1979) found certain stages of $H$. simondi Laveran et Mesnil, 1901 in leukocytes and erythrocytes, while Barber et al. (1987) described stages of $H$. nototheniae Barber, Mills Westermann et Storoz, 1987 as a new species. The presence of certain developmental haemogregarine forms in leukocytes of the peripheral blood and internal organs of mackerel, Scomber scombrus, were reported by MacLean and Davies (1990).

In this paper, the development of haemogregarines in the peripheral blood and internal organs of naturally infected eel is described.

\section{MATERIAL AND METHODS}

The present study is based on the materials collected mainly for evaluating the health of and for performing haematological assay on eel, Anguilla anguilla (L.) in water bodies of the north-western Poland (Orecka-Grabda 1986, 1993). The fish were obtained from commercial catches effected within 1970-1973 in the Szczecin Lagoon and in lakes Dąbie, Siecino, Drawsko, and Lipiany. A total of 820 individuals measuring 32-89 cm (longitudo totalis) and weighing 50-1190 $\mathrm{g}$ were examined. The age of the fish examined ranged within $1+$ to $11+$ (not including the larval period).

After delivery to the laboratory, the fish were kept for up to 3 days in the aquarium. The blood was collected from vessels in the caudal part of the body; smears were prepared from one drop of blood. During a detailed anatomopathological autopsy, imprints of the liver, spleen, and three kidney sections were made. After drying, the mounts were MayGrünwald and Giemsa stained.

\section{RESULTS}

Out of the 820 individuals examined, haemogregarines were found in 23 (2.8\% infection). The infected fish had been caught in Lake Siecino (18 individuals), Lake Dąie (4 individuals), and Lake Drawsko (1 fish).

Early merogony stages were found to occur, in leukocytes and extracellularly, mainly in the liver and kidney. The parasites were rounded, somewhat oval, and seldom bean- 

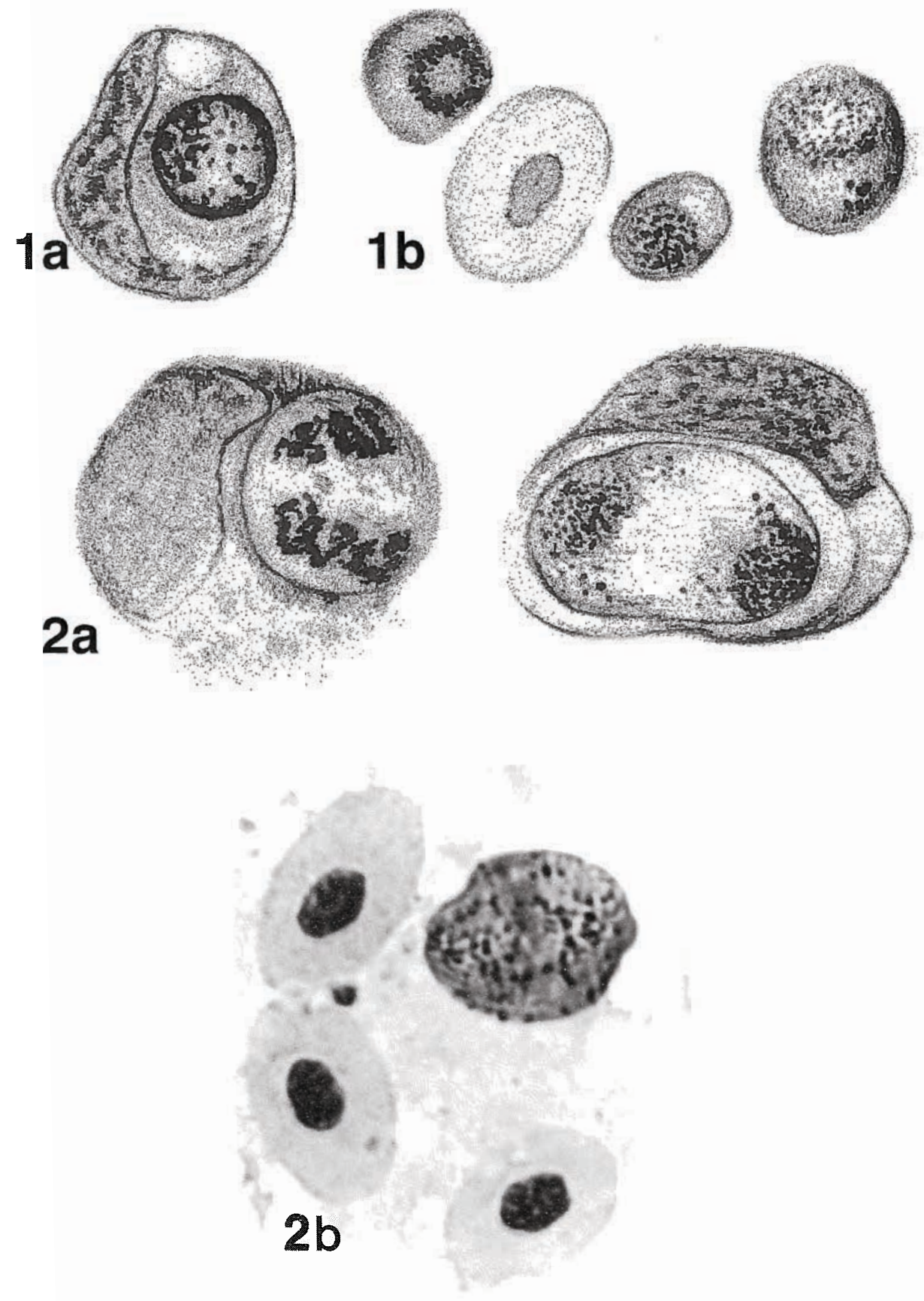

1-2. Early haemogregarine merogony stages in eel; 1a, 2a-in leukocytes; $1 \mathrm{~b}, 2 \mathrm{~b}$ - extracellular occurrence 

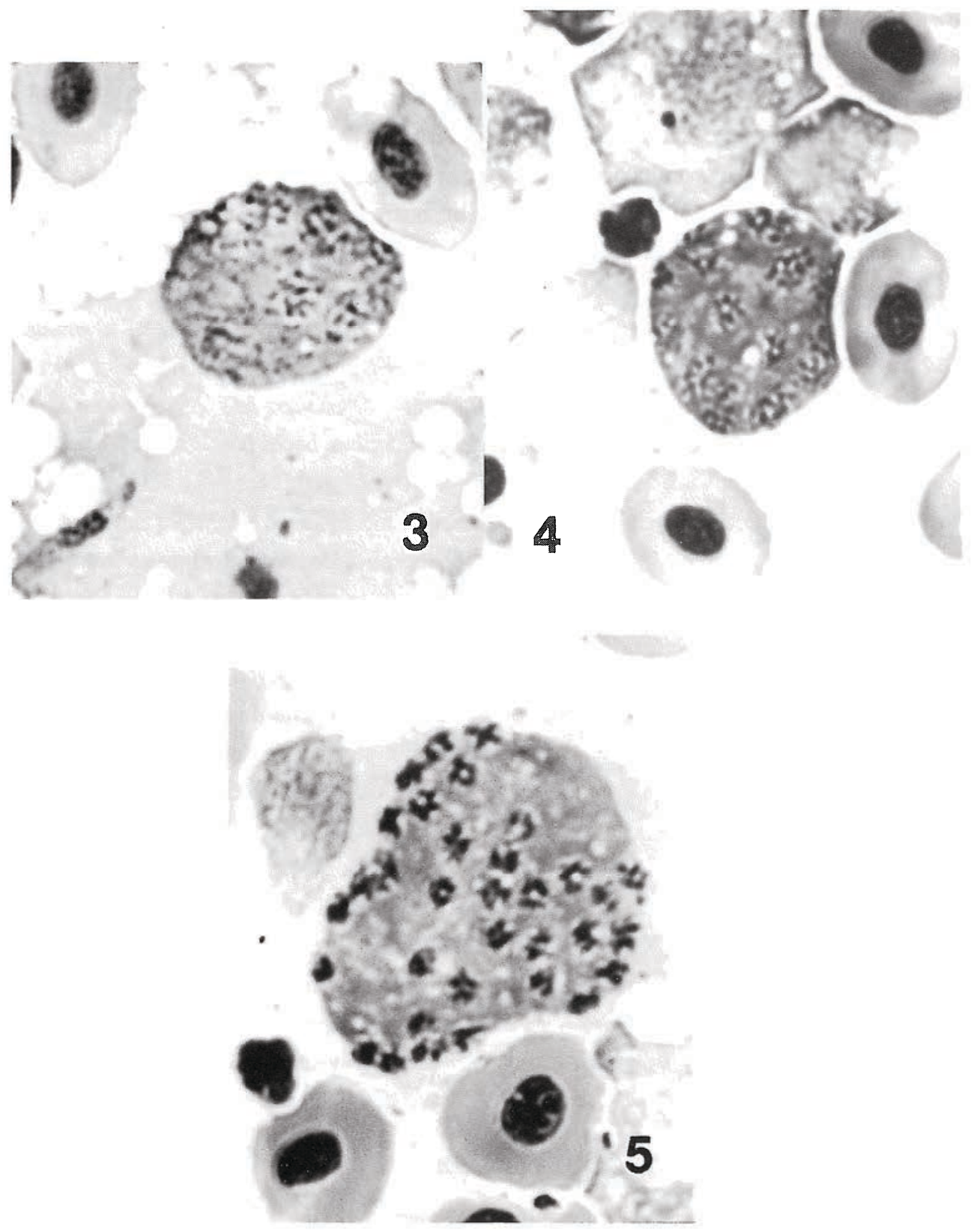

Figs 3-5. Stage-wise course of merogony with different chromatin aggregation within cells 


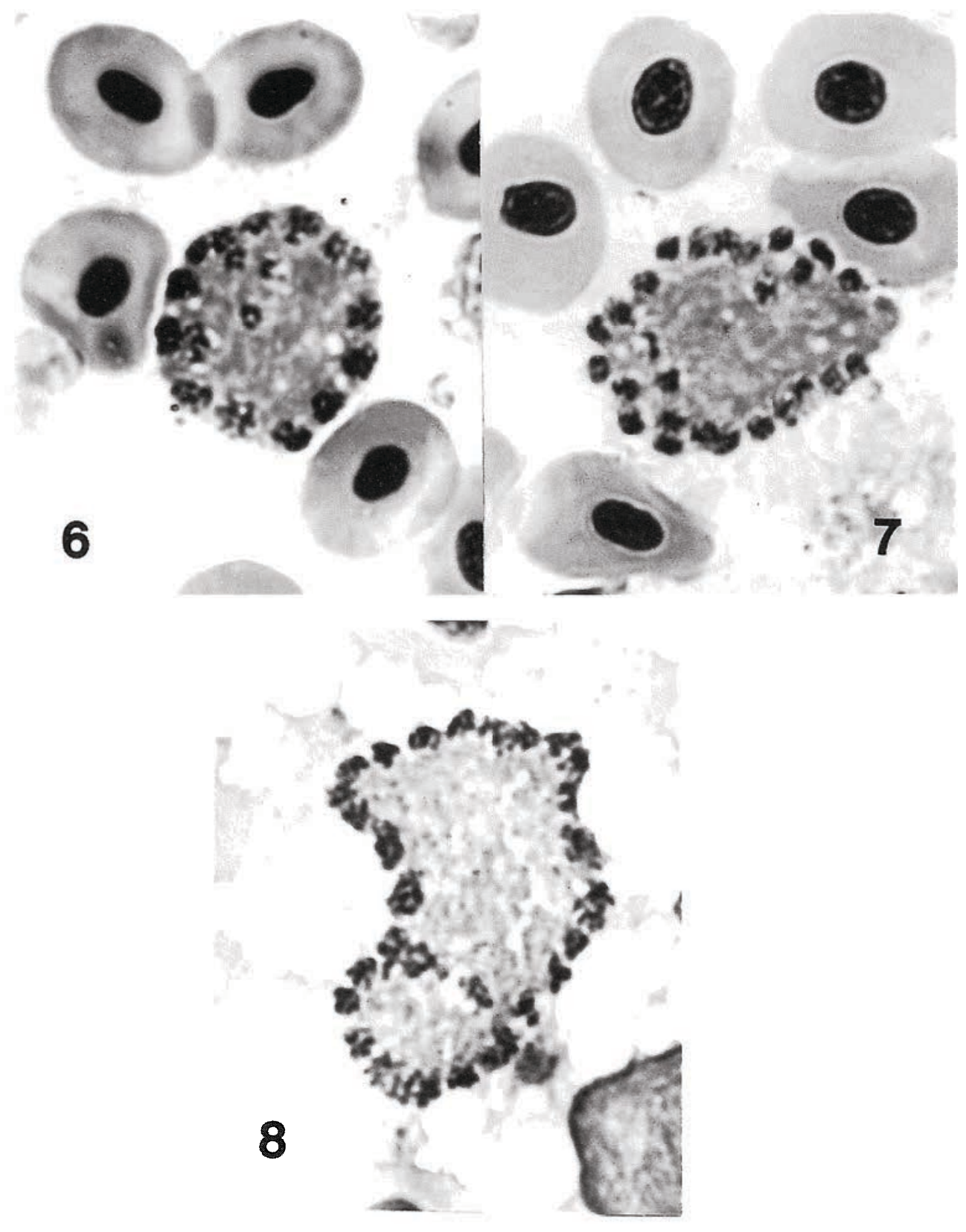

Figs 6-8. Merogony stages with chromatin aggregations shifted to the cell periphery 


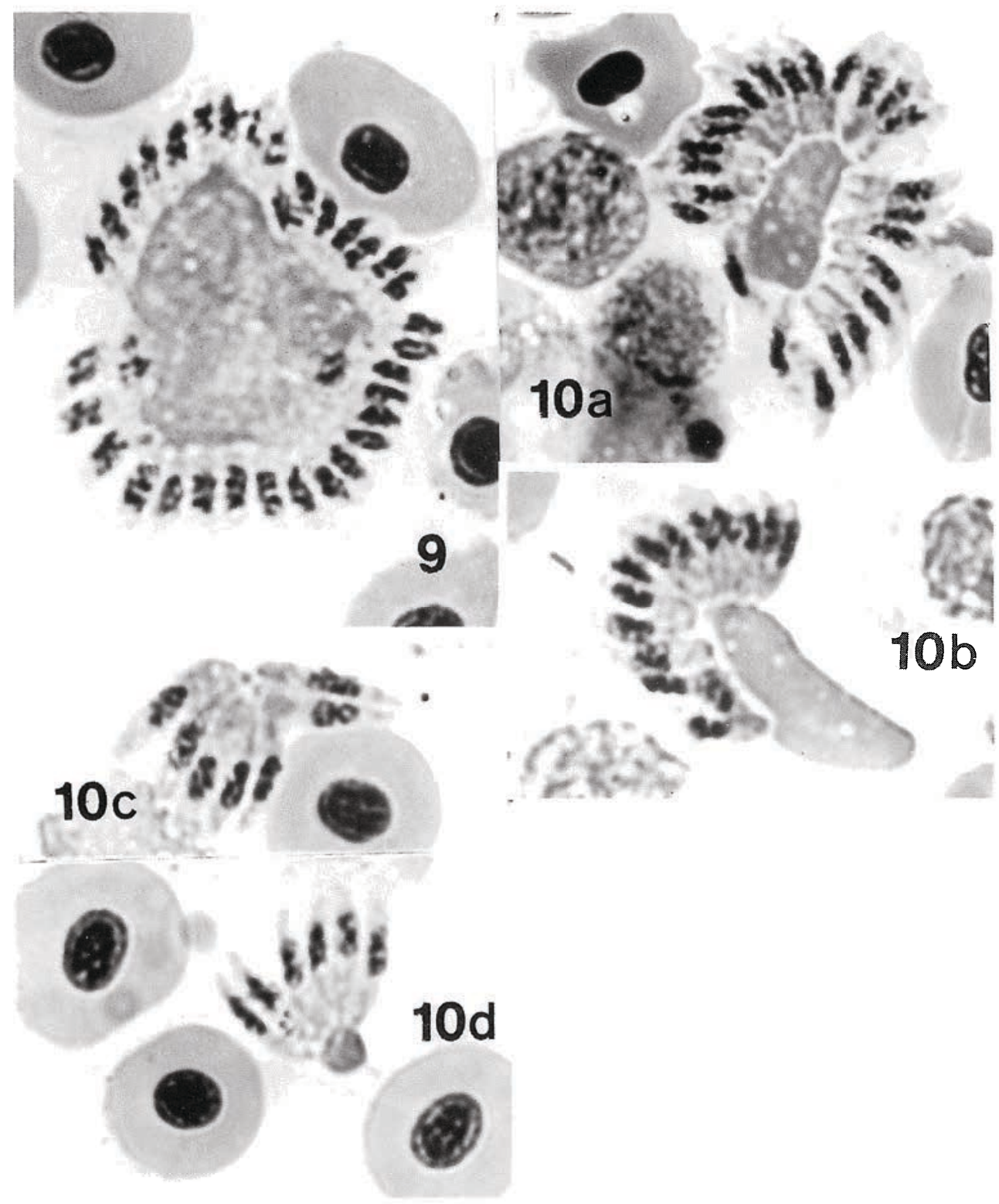

Figs 9-10. Meronts with well-formed merozoites connected with the residual body 

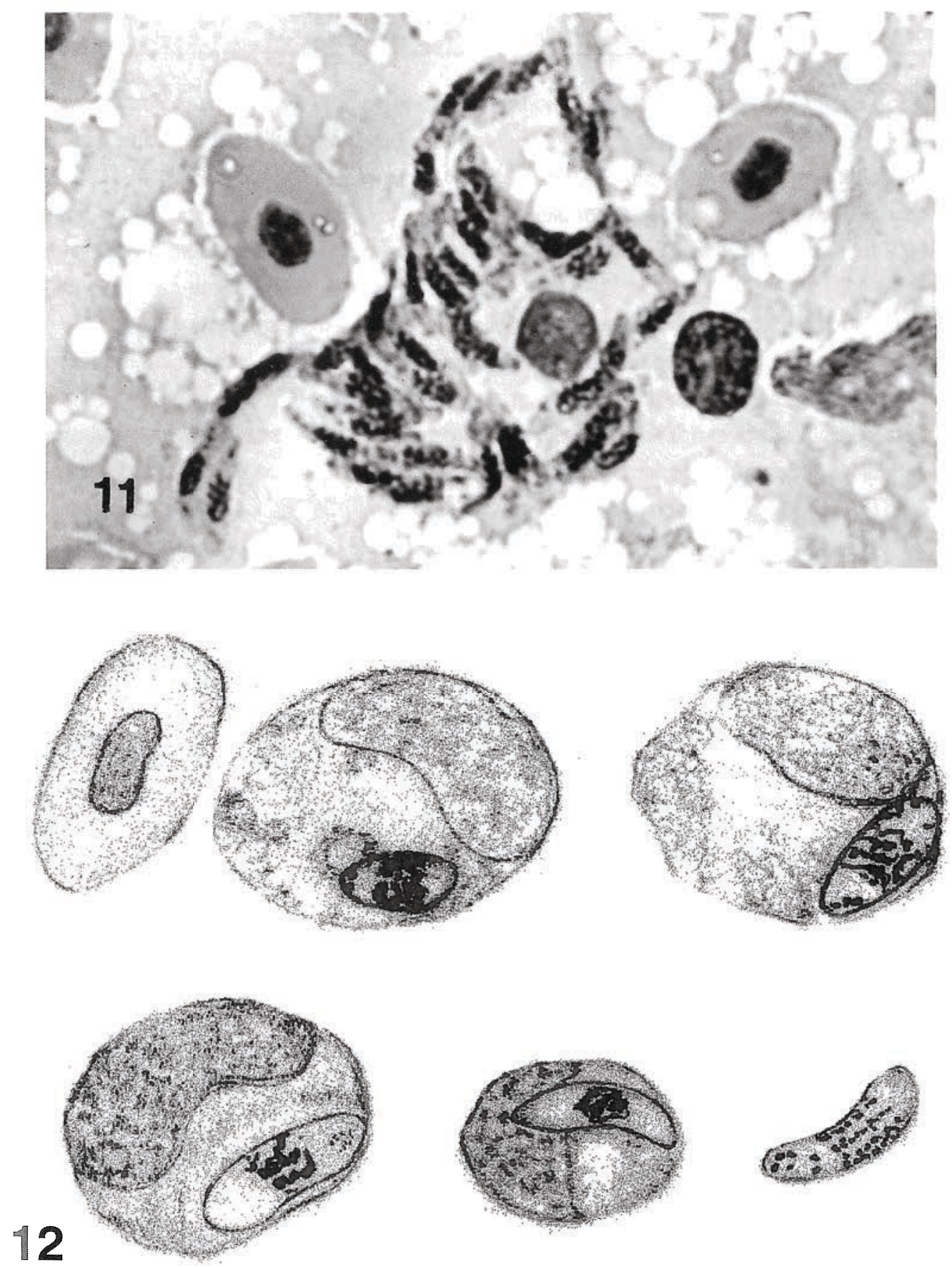

Fig. 11. A group of free merozoites

Fig. 12. Gamonts occurring in leucocytes and extracellularly 
shaped, and contained dark-blue cytoplasm. The finely granulated nuclear chromatin occupied an extensive space in the cell and was arranged in circles, occasionally with a slight gap (Fig. 1a, b). Those individuals measured 5.5-9.5 × 5.0-7.5 $\mu \mathrm{m}(\mathrm{n}=10)$. In the following stage, the chromatin was scattered all over the cell and then began to gather at the opposite poles as two more or less compact accumulations (Fig. 2a, b). Those forms measured 9.0 $12.5 \times 7.5-9.5 \mu \mathrm{m}(\underline{n}=5)$.

The subsequent meront stages contained 4, 8, 16, and 32 compact chromatin accumulations situated inside rounded or oval individuals with blue cytoplasm (Figs 3-5), measuring 9.5-23.5 × 8.0-20.0 $\mu \mathrm{m}(\mathrm{n}=15)$. The number of chromatin aggregations varied slightly between different stages. The meronts occurred as free forms in the liver, kidney, and spleen and in the peripheral blood. In addition, an older stage was found in which the chromatin aggregations $(16,26$ or about 32 ) were placed peripherally (Figs $6-8)$. Those individuals measured 16.0-22.5 × 15.0-19.0 $\mu \mathrm{m}(\mathrm{n}=5)$.

On the periphery of the final merogony stage, well-developed merozoites were visible connected with round or deformed residual body (Figs 9-10). The materials examined contained up to 16,24 , about 32 , and 39 merozoites surrounding the residual body. Those forms measured up to $30.0 \times 22.0 \mu \mathrm{m}(\mathrm{n}=5)$ in total size, the residual body size and merozoite length ranging within 4.5-20.0 $\times 3.5-15.0 \mu \mathrm{m}$ and 5.5-7.5 $\mu \mathrm{m}$, respectively. The smears showed also irregularly arranged groups of 32 and about 40 merozoites with fragments of the residual body or lacking it altogether (Fig. 11).

Free merozoites occurred in the peripheral blood, liver, kidney, and spleen. Up to 5 individuals per field of vision (at $10 \times 100$ magnification) were observed. The merozoites were elongated and most often somewhat curved (crescent-like), with one or both ends slightly tapered. The mid-part contained fairly compact nuclear chromatin. The pale-blue cytoplasm was sometimes observed to contain single, fine, basophilous granulations located predominantly near one pole of a cell. The merozoites measured 7.5-12.5 $\mu \mathrm{m}$ in length and $1.5-2.0 \mu \mathrm{m}$ in width, the nuclear chromatin aggregations being $2.3-4.5 \mu \mathrm{m}(\mathrm{n}=30)$ long. Those forms were only exceptionally present in leukocytes and very rare in erythrocytes. Those present were similar in size to the above-described forms.

Gamonts, differing from merozoites mainly in shape and thickness, were occasionally encountered in the liver, kidney, and spleen. They were observed within the leukocytes and, seldom, extracellularly. They were oval, slightly elongated or crescent-like in shape, their tips being rounded and, seldom, one of them tapered slightly. The nuclear chromatin, thickened to the form of coarse granulations situated in the central part of a cell, occupied almost one-third of it. The cytoplasm was slightly basophilous (Fig. 12). Some individuals contained single chromatophilous granules located most often near one pole. The forms described measured 7.0-11.0 × 3.0-4.0 $\mu \mathrm{m}(\mathrm{n}=10)$. 


\section{DISCUSSION}

In this study, the haemogregarine life cycle in the eel blood was followed. So far, in erythrocytes only have some haemogregarine forms been found in this fish host. Franca (1908) described them as Haemogregarina bettencourti and Laveran (1906) identified them as H. lignieres (both references after Franca 1908). The shape and size of small and medium-sized forms of $H$. lignieres from the peripheral blood as well as $H$. bettencourti individuals from internal organs, described by the authors referred to, resembled to some extent the gamonts and were observed predominantly in leukocytes and, seldom, extracellularly in the liver, kidney, and spleen. On the other hand, the H. bettencourti individuals found in the peripheral blood erythrocytes as well as large forms of $H$. lignieres differed from the gamonts described in this paper. Neither Laveran nor Franca found any developmental stages in their materials. In their opinion, confirmed by this study, haemogregarine infection of eel is very rare and occurs in inland waters only.

There are very few characters that can be used for haemogregarine identification; knowledge on the full life cycle is indispensable for identification as weli. Taxonomic identification of the haemogregarines we observed, due to differences with respect to the two species described earlier from eel, is problematic.

The haemogregarine development followed in eel shows some resemblance to certain stages of merogony found in leukocytes of the peripheral blood as well as the spleen and kidney of mackerel, described by MacLean and Davies (1990). They found few meronts only, with up to 20 chromatin aggregations per individual. On the other hand, their materials contained numerous non-identified elongated, single forms present in leukocytes. It was from leukocytes, too, that Barber et al. (1987) reported certain stages of merogony, belonging to $H$. nototheniae, in the marine fish Notothenia neglecta and $N$. rossii. They described micro- and macromeronts with different amounts of intracellular nuclear chromatin aggregations, the gamonts being formed in erythrocytes.

The merogony described here shows some similarity to that in Cyrilia uncinata, described by Khan (1978). That author found meronts at various stages of development, from the youngest to the oldest, which produced 14 and 30 merozoites. Subsequently, gamonts - of a size five times that of the merozoites-were formed. Apart from differences in merozoite and gamont shape and size, another difference concerned the development site: C. uncinata developed exclusively in erythrocytes, while the eel haemogregarines described here developed predominantly in leukocytes and extracellularly. As reported by Molnar (1995), at some developmental stage merozoites can form gamonts also in leukocytes, which was the case in this study. 


\section{RECAPITULATION}

1. Haemogregarines as the eel blood parasites have seldom been recorded in the literature; they were not common in the eel health survey touched upon in this study $(2.8 \%$ infection).

2. The eel haemogregarine life cycle involved different stages of merogony and forms of gamogony.

3. The gamogony, during which gamonts are formed, is the final stage in the haemogregarine development in the fish host.

\section{REFERENCES}

Barber D.L., J.E. Mills Westermann, P. Storoz, 1987: Haemogregarina nototheniae n. sp. from the blood of Antarctic nototheniids. Syst. Parasitol., 10: 135-147.

Davies A.J., 1982: Further studies on Haemogregarina bigemina Laveran \& Mesnil, the marine fish Blennius pholis L., and the isopod Gnathia maxillaris Montagu. J. Protozool., 29, 4: 576583.

Davies A.J., J.C. Eiras, R.T.E. Austin, 1994: Investigation into the transmission of Haemogregarina bigemina Laveran \& Mesnil, 1901 (Apicomplexa: Adeleorina) between intertidal fishes in Portugal. J. Fish Diseases, 17: 283-289.

Eiras J.C., A.J. Davies, 1991: Haemogregarina bigemina Laveran \& Mesnil, 1901 (Protozoa, Apicomplexa) from Blennius pholis L. (Osteichthyes, Blenniidae): an investigation of seasonality in Portugal. J. Fish Diseases, 14: 683-687.

Eiras J.C., M.J.T. Ranzani-Paiva, A.J. Davies, 1995: Observations on Haemogregarina mugili (Apicomplexa) and Trypanosoma froesi (Sarcomastigophora) from the blood of Mugil platanus Gunther, 1880 (Pisces: Mugilidae) in Brazil. Res. Rev. Parasitol., 55, 3: 173-176.

Franca C., 1908: Une Hémogrégarine de l'Anguille. Arch. Real Inst. Bacteriologia Câmara Pestana, 2: $109-112$.

Khan R.A., 1972: Developmental stages of Haemogregarina delagei Laveran and Mesnil in an elasmobranch, Raja radiata Donovan. Can. J. Zool., 50: 906-907.

Khan R.A., 1978: A new hemogregarine from marine fishes. J. Parasitol., 64, 1: 35-44.

Khan R.A., W. Threlfall, W.S. Whitty, 1992: Hematozoa of deep-sea demersal fish of the Northwest Atlantic Ocean. Can. J. Zool., 70: 1926-1933.

Kirmse P., 1979: Redescription of the life cycle of Haemogregarina simondi (Laveran and Mesnil, 1901) in its vertebrate host the marine fish Solea solea (Linnaeus). Zeitschr. Parasit., 59: 141150.

Laird M., W.L. Bullock, 1969: Marine fish haematozoa from New Brunswick and New England. J. Fish. Res. Board Canada, 26: 1075-1102.

Lom J., I. Dyková, 1992: Protozoan parasites of fishes. Elsevier, Amsterdam-London-New YorkTokyo: 87-95.

MacLean S.A., A.J. Davies, 1990: Prevalence and development of intraleukocytic haemogregarines from Northwest and Northeast Atlantic mackerel, Scomber scombrus L. J. Fish Diseases, 13: $59-68$.

Molmár K, 1995: Phylum Apicomplexa. In: Fish diseases and disorders 1. Protozoan and metazoan infections [P.T.K. Woo (ed.)]. Univ. Press, Cambridge: 263-287. 
Orecka-Grabda T., 1986: Hematological, clinical and anatomical pathology of the European eel (Anguilla anguilla $\left(\mathrm{L}_{.}\right)$) from polluted waters of Northwestern Poland. Acta Ichth. Piscat., 16, 1: 107-127.

Orecka-Grabda T., 1993: A preliminary evaluation of health condition of eel (Anguilla anguilla (L.)) from the Szczecin Lagoon in 1971-1973 and 1982-1983. Acta Ichth. Piscat., 23, 2: 113129.

Teresa ORECKA-GRABDA, Jadwiga WIERZBICKA

\section{ROZWÓJ HAEMOGREGARIN (APICOMPLEXA) PASOŻYTÓW KRWI WĘGORZA, ANGUILLA ANGUILLA (L.)}

\section{STRESZCZENIE}

U przebadanych 820 węgorzy, Anguilla anguilla (L.), pozyskanych z Zalewu Szczecińskiego i jezior: Dąbie, Siecino, Drawsko oraz Lipiany (północno zachodnia Polska), haemogregariny znaleziono u 23 ryb (2,8\%). Głównie w leukocytach i pozakomórkowo, rzadziej w erytrocytach krwi obwodowej, wątrobie, śledzionie i nerce występowały różne stadia cyklu. Prześledzono proces merogonii $\mathrm{z}$ różnymi stadiami $\mathrm{z}$ pogrupowaną chromatyną jądrową $\mathrm{w}$ liczbie $2,4,8,16,32$ i więcej wewnątrz komórki. W dalszym procesie różnicowania następowało przemieszczenie skupisk chromatyny na obwód, a następnie tworzenie się poprzez wyodrębnienie poszczególnych merozoitów (w liczbie do $32 \mathrm{i}$ więcej) przyczepionych do ciałka resztkowego. Uwolnione merozoity rozproszone były międzykomórkowo. $\mathrm{W}$ procesie gamogonii powstawały formy $\mathrm{z}$ cechami gamontów, jako stadium kończące rozwój w żywicielu rybie.

Received: 20 May 1998

Author's address:

Teresa Orecka-Grabda, PhD DSc, Prof.

Department of Animal Ecology

Szczecin University

Felczaka 3a, 71-412 Szczecin, Poland

Jadwiga Wierzbicka PhD DSc

Department of Fish Diseases

Agricultural University of Szczecin

Kazimierza Królewicza 4, 71-550 Szczecin, Poland 